\title{
The distribution of soil morphological characteristics for landslide-impacted Sumbing Volcano, Central Java - Indonesia
}

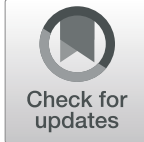

\author{
Amir Noviyanto ${ }^{*} \mathbb{D}$, Junun Sartohadi ${ }^{2}$ and Benito Heru Purwanto ${ }^{2}$
}

\begin{abstract}
Landslides are the second biggest natural disasters in Indonesia, occurring mostly in volcanic area with thick and clay rich soils. Examining the changes of land surface and soil morphology brought about by a particular landslide is usually the first step required for vegetative rehabilitation. Most examinations to date, however, have been based on general characters rather than on soil morphology, including physical and chemical characteristics of the soil, which are usually locally specific. This study investigates the morphological characteristics of soil in a landslideprone slope region of Sumbing Volcano, in Central Java Province of Indonesia. The field investigations are conducted at three landslides sites. It starts with interpreting small format areal-photographs which have been geocorrected, followed by the delineation of landslide zones (i.e. crowns, main scarps, heads, bodies and toes) based on morphological analysis of the landslide sites. Finally, identification of morphological, physical and chemical characteristics of the soil in each of the landslide zones are conducted in the field, along with laboratory tests. The results demonstrate that soil morphology is unique for each of the landslide zones. The characters of the undisturbed soil, as indicated by well-defined genetic horizons, are found in the crown zones. Outcrop of high clay content soil material layers are seen in the main scarp zones. Meanwhile pedoturbation processes are evident in the zone of bodies and toes, suggesting that the soil is prone for erosion. If natural erosions in these zones are not controlled and/or unmitigated, the situation will trigger landslide reactivations. We suggest that in studying landslide, one also considers the characters of soil morphology, as this additional information provides a more complete understanding of both land surface morphology and soil morphology to inform landslide vegetative rehabilitation.
\end{abstract}

Keywords: Soil morphology, Landslide, Clay layer, Slope stability, Volcanic landscape

\section{Introduction}

Landslides generally occur in mountainous and hilly areas with thick soil and/or weathered rock, and in volcanic landscape over humid tropical regions. Landslides in volcanic landscapes occur because of the weakening of mountain topography due to volcanic parent rocks that are affected by hydrothermal alteration processes. Landslides that occur in the hydrothermal alteration area

\footnotetext{
* Correspondence: noviyantoamir@gmail.com

${ }^{1}$ Master Program in Soil Science, Universitas Gadjah Mada, Yogyakarta, Indonesia

Full list of author information is available at the end of the article
}

can be influenced by the swelling clay mineral-bearing hydrothermal alteration types, dip slope angle, and cap rock (Maeda et al., 2012). Hydrothermal alteration process that has been running in the past can affect the increase in clay content. The high percentage of clay minerals significantly reduced parent rock strength and facilitated the slope failure (Regmi et al., 2013).

Landslides are an important factor in the evolution of landforms (Glade and Crozier, 2010), soil properties, and biotic agents, including vegetation and fauna (Sidle and Ochiai, 2006). Landslides can redistribute sediment material to areas with relatively less steep slopes. Landslides

\section{Springer Open}

(c) The Author(s). 2020 Open Access This article is licensed under a Creative Commons Attribution 4.0 International License, which permits use, sharing, adaptation, distribution and reproduction in any medium or format, as long as you give appropriate credit to the original author(s) and the source, provide a link to the Creative Commons licence, and indicate if changes were made. The images or other third party material in this article are included in the article's Creative Commons licence, unless indicated otherwise in a credit line to the material. If material is not included in the article's Creative Commons licence and your intended use is not permitted by statutory regulation or exceeds the permitted use, you will need to obtain permission directly from the copyright holder. To view a copy of this licence, visit http://creativecommons.org/licenses/by/4.0/. 
impact soil deficit, sediment transportation and accumulation, soil material mixing, and material enrichment in deposition zone. Changes in soil characteristics in the sliding area can decrease soil organic matter and plant nutrition (Sparling et al., 2003). The debris and pedoturbation of parent material in the landslide deposition areas can re-supply nutrients to acidic soils that have undergone intense weathering (Schrumpf et al., 2001; Sartohadi et al., 2018).

Java Island has a high-density volcanic structures, resulting in fertile soil and productive agricultural land, especially over the volcanic areas. However, landslides often disturb such agricultural lands. For example, landslide are threats to the Sumbing Quaternary volcanic system and Menoreh Tertiary structural-volcanic system, where the agricultural sector in the region serves as the main livelihood for civil society and supports national food security.

Sartohadi et al. (2018) shows that volcanic transitional landscapes have unique geological relationship with soil, because they are formed due to intense weathering tephra and/or undergo hydrothermal alteration that resulted in heavily altered volcanic rock characteristics. Variations in volcanic rock and soil characteristics with clay-rich content can potentially form a slip plane in the lithological discontinuity layer. Only few studies have attempted to investigate the changes in soil characteristics caused by landslides, therefore further researches are required.

It is also learnt that the damages caused by landslide have stimulated the development of mitigation strategies to prevent further deterioration on utilized landslideprone area. A research related to the landslide deposition zone (Candraningrum, 2017) reported an association between microrelief and physical characteristics of surface soil material in a former landslide zone at the Bompon watershed, which is located in a transitional volcanic landscape, in Central Java. Other studies on soil characteristics in landslide deposits were carried out in different lithological areas and characteristics. Examples include a research in Uganda by (Van Eynde et al., 2017) which reported the impact of landslides on changes in the soil surface characteristics of the upper layers and the predicted recovery time of soil characteristics. A research in Taiwan by (Cheng et al., 2016) reported changes in the physicochemical properties of land caused by landslides. These three studies emphasized the importance of providing basic information on the different section of the landslide is expressing different characteristics for rehabilitation, management, and development of land resources in landslide areas.

Landslides occurs every year in the mountainous and hilly areas of Central Java (Marfai et al., 2008). Landslides have become a serious threat in the Menoreh Tertiary Structural-
Volcanic Mountains as there is connection between physical-natural factors and an increase in human population and land-use change (Hadmoko et al., 2010). Landslides are controlled to some extent by mainly two factor: (1) the groundwater and rugged topography with high slope angles (Regmi et al., 2013) and (2) the presence of clay layers contributes to slope failure or instability (Sartohadi et al., 2018). The level of soil movement is particularly determined by the value of the safety factor and the shear zone of the clay layer on a slope. The clay displays a strain-softening behaviour which can be attributed to a change in material properties like friction angle and cohesion (Gylland et al., 2013). The physical and mechanical properties of soil are influenced by the level of soil development through the pedogenetic processes.

According to data from the National Disaster Management Agency (2019), there are 180 landslides have occurred in the past 10 years. Landslide therefore becomes a priority area for natural disaster management. Various studies that have been carried out earlier have provided information on landslide-prone areas maps, the application of landslide management methods, and the identification of landslide mechanisms. Only few researches have attempted to provide information regarding changes in soil characteristics after a landslide. Research on the detail and local re-distribution of landslide sediment at the former landslide areas has not been widely reported.

This study aimed to investigate the morphological characteristics of the soil in the landslide-prone slope region on the southern flank of Sumbing Volcano, in the Central Java Province of Indonesia. This study is conducted on three active "rotational slide" to demonstrate the similarity of the landslide sediment distribution pattern as well as land surface morphological units. This study also develops data of shear zones and slope safety factors, which can give insight into the patterns of slope failure due to clay layers. The landslide area was divided into five parts, namely crowns, main scarps, heads, bodies, and toes. The three landslide study sites are located in the transitional volcanic landscape systems which have very thick soil layer, relatively high clay content, under humid-tropic climates, and intensive erosion and landslides processes (Sambodo et al. 2018). Detailed observations and analyses have been carried out to provide better understanding on patterns of change in soil properties due to landslides and on slope failures due to clay layers in volcanic transitional landscapes.

\section{Material and method}

\section{Study area}

The research was conducted on three active landslide areas (Fig. 1). The three locations are located to the south of the Sumbing Volcano, which is a transitional 


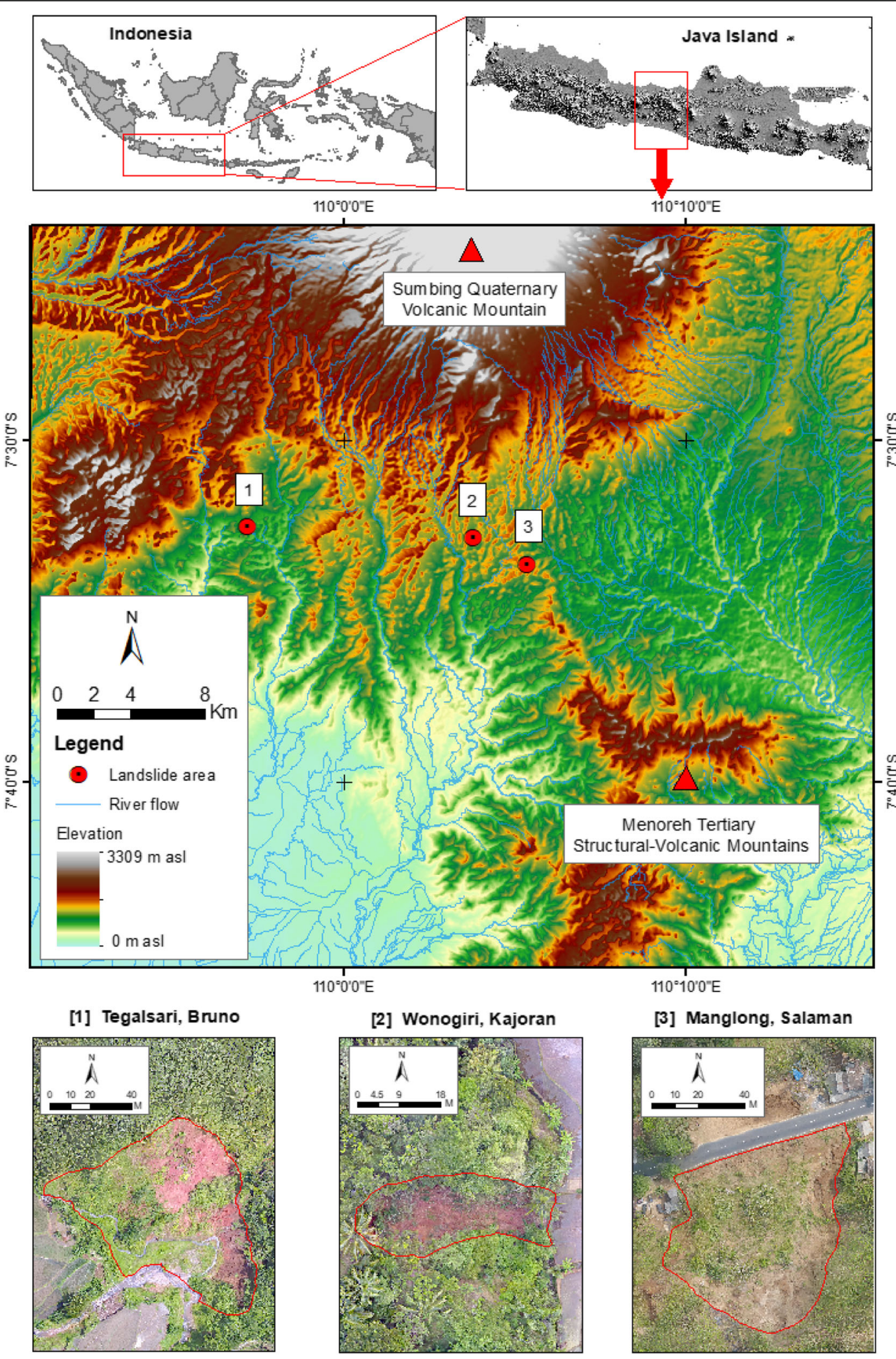

Fig. 1 Location of the landslide study area 
landscape between quarternary and tertiary volcanoes. Descriptions of the three landslide study sites are presented in Table 1.

Both study sites in Wonogiri and Manglong belong to the Kebobutak geological formation with late Oligocene age to early Miocene, while the site in Tegalsari belongs to Halang geological formation with late Miocene to early Pliocene. All geological formations have been covered by quaternary tephra deposits with varying degrees of weathering and thickness. Hydrothermal altered andesite breccia rocks are found in the Kebobutak Formation, whereas clay rocks and sand rocks are found inside the Halang Formation. Both Halang and Kebobutak Formations consist of clay rock, sand rock, and tuff in a different position and composition (Van Bemmelen, 1949). Hydrothermal alteration in the past has caused most of the tertiary rocks on southern flank of Sumbing Volcano to form heavy weathering profile (Sartohadi et al., 2018). Tephra deposits from the Sumbing Volcano during the Quarternary period results in thick surface soil overlaying the heavily weathered zone of Tertiary rocks (Wida et al., 2019). Weathering processes in the surficial tephra deposit form highly clay textural characteristic in the soil, especially in the lithological discontinuity between clay-rich content and weathered parent rock (Pulungan and Sartohadi, 2018a). All the three study sites are located in the steep slope zone with very thick soil and high clay content.

\section{(1) Landslide in Tegalsari; (2) landslide in Wonogiri; (3) landslide in Manglong \\ Survey and sampling design}

Aerial photo technology was used to obtain orthophoto of landslide areas. The method to capture aerial photograph was based on unmanned aerial vehicles (UAV) DJI Phantom version 4.0-pro. UAV DJI Phantom was operated using the Pix4D application which is an opensource software. The steps for aerial photo acquisition using UAV and Pix4D are as follows: (1) UAV track (called a mission) is created in the Pix4D application. The mission grid extent is adjusted with the information about total area extent to be captured, flight height, and the flight duration (2) The flight setting is adjusted in Pix4D to control camera angle, output photos overlap, and UAV speed (3) The UAV is connected to pix4D application until the mission has been completed (4) After all the settings are set, the UAV is taken off with a flying altitude of less than $80 \mathrm{~m}$ in order to capture the aerial photo in landslides area. The collection of all captured aerial photos is subsequently combined into a single mosaic. The steps for combining all photos into a single mosaic using Agisoft 1.1 are: importing photos, aligning photos, building a dense cloud, building mesh, building texture, building tiled model, building digital elevation model, building orthomosaic, and exporting results. The on-screen digitization was done using ArcGIS 10.5 software.

The ground control points (GCP) of the research site were marked using differential global positioning system (DGPS) on objects that would have not been impacted or changes by the landslides. The GCP are used to assess root mean square error (RMSE) in orthophoto. The RMSE calculation is used to evaluate the level of accuracy of the resulting orthophoto, the smaller the RMSE value indicates a better geometrical accuracy of orthophoto. Table 2 presents the details of UAV flight information and Fig. 2 presents measurements of GCP in the research site.

The determination of observation points and soil sampling was carried out in a transect line, which crosses the landslide slope from the crown to the toe parts. Each part of the landslide zones was taken as a representative profile for observing the morphology of the soil (Fig. 3). It is used to determine changes due to the slides and the pedoturbation of the soil. Results found in each soil observation at a given point were compared with the original soil in the landslide crown. The changes in soil morphological characteristics were analyzed qualitatively and quantitatively.

\section{Sample and data analyses}

Fourteen soil profiles and sixty-five horizons have been analyzed qualitatively and quantitatively. Qualitative analysis were based on observation of soil morphological characteristics, which were conducted using the USDA standard Field Book procedures for Describing and Sampling Soils (Schoeneberger et al., 2012), but with a slight modification to adjust with the research objectives. Site observations were carried out to determine the geographical position, altitude, slope, and vegetation. Soil

Table 1 Descriptions of three landslide study sites

\begin{tabular}{|c|c|c|c|c|}
\hline Location & Coordinat & Elevation & Area & Perimeter \\
\hline Tegalsari, Bruno, Purworejo & $\begin{array}{l}109^{\circ} 57^{\prime} 11.86^{\prime \prime} \mathrm{E} \\
7^{\circ} 32^{\prime} 32.77^{\prime \prime} \mathrm{S}\end{array}$ & $334 \mathrm{~m}$ asl & $5410.55 \mathrm{~m}^{2}$ & $327.33 \mathrm{~m}$ \\
\hline Wonogiri, Kajoran, Magelang & $\begin{array}{l}110^{\circ} 3^{\prime} 46.61 " \mathrm{E} \\
7^{\circ} 32^{\prime} 52.77^{\prime \prime} \mathrm{S}\end{array}$ & $449 \mathrm{~m}$ asl & $569.94 \mathrm{~m}^{2}$ & $108.13 \mathrm{~m}$ \\
\hline Manglong, Salaman, Magelang & $\begin{array}{l}110^{\circ} 5^{\prime} 22.28^{\prime \prime} \mathrm{E} \\
7^{\circ} 33^{\prime} 38.24^{\prime \prime} \mathrm{S}\end{array}$ & $445 \mathrm{~m}$ asl & $2878.91 \mathrm{~m}^{2}$ & $288.46 \mathrm{~m}$ \\
\hline
\end{tabular}


Table 2 UAV flight information

\begin{tabular}{|c|c|c|c|c|}
\hline Landslide location & Area captured $\left(\mathrm{m}^{2}\right)$ & Number of photographs & Number of GCPs & Total RMSE \\
\hline Tegalsari & 120,411 & 81 & 4 & 0.0646209 \\
\hline Wonogiri & 57,273 & 59 & 4 & 0.0744468 \\
\hline Manglong & 47,216 & 64 & 4 & 0.0708227 \\
\hline
\end{tabular}

profile description was subjected for horizon thickness, horizon topography, horizon distinctness, soil color, soil penetration, root quantity, root size, soil structure grade, soil structure size, soil structure type, and soil consistency in three conditions (dry, moist, and wet). Soil sampling for quantitative analysis in the laboratory was performed on disturbed and undisturbed soils. Undisturbed soil samples are used for the analysis of saturated hydraulic conductivity (permeameter method) and bulk density (ring method). Analysis of other soil characteristics such as particle density (pycnometer method), soil texture (pipette method), soil particle size criteria was based on USDA classification: clay $(\Phi:<0.002 \mathrm{~mm})$, silt (Ф: $0.05 \mathrm{~mm}-0.002 \mathrm{~mm}$ ) and sand (Ф: $2 \mathrm{~mm}-0.05$ $\mathrm{mm})$, soil porosity, and soil organic carbon was carried out using disturbed soil samples. The clay layer is determined from its depth (more than $2 \mathrm{~m}$ ) and has a high clay content (more than $60 \%$ ).

The stability of the slope is analyzed using the factor of safety (F) with a simple calculation. The safety factor based on the value of the comparison between the holding force and the moving force. Analysis of infinite slope stability is used to determine the level of slope stability at the research site. The infinite slope assumption is based on a slope length greater than the depth or thickness of the soil $(\mathrm{H})$. Slope stability is very dependent on the value of cohesion and internal friction angle obtained from the triaxial test. The formula for calculating the safety factor is based on the concept of the Coulomb stress.

$$
F=\frac{c}{\gamma \cdot H \cos ^{2} \alpha \cdot \tan \alpha}+\frac{\tan \Phi}{\tan \alpha}
$$

Where,

$\mathrm{F}=$ safety factor.

$\mathrm{c}=$ cohesion $\left(\mathrm{kN} \cdot \mathrm{m}^{-2}\right)$.

$\gamma=$ bulk density $\left(\mathrm{kN} \cdot \mathrm{m}^{-3}\right)$.

$\mathrm{H}=$ soil thick $(\mathrm{m})$.

$\alpha=$ slope $\left(^{\circ}\right)$.

$\Phi=$ internal friction angle $\left({ }^{\circ}\right)$.

Slope stability analysis is intended to determine the safety factor of a potential slip plane of a landslide. In another words, a slope can be said to be stable and unstable. The slope stability classification proposed by Ray and De Smedt (2009) is presented in Table 3.

The topographic analysis was obtained from the derivation of the digital elevation model (DEM) from image processing using UAV. The considered topographic indicators are: the slope angle and terrain ruggedness index (TRI). A quantitative DEM analysis was used to determine the distribution of safety factor values in landslide areas. The process of mapping the value of safety factor used the raster calculator tool in the ArcGIS 10.5 program.

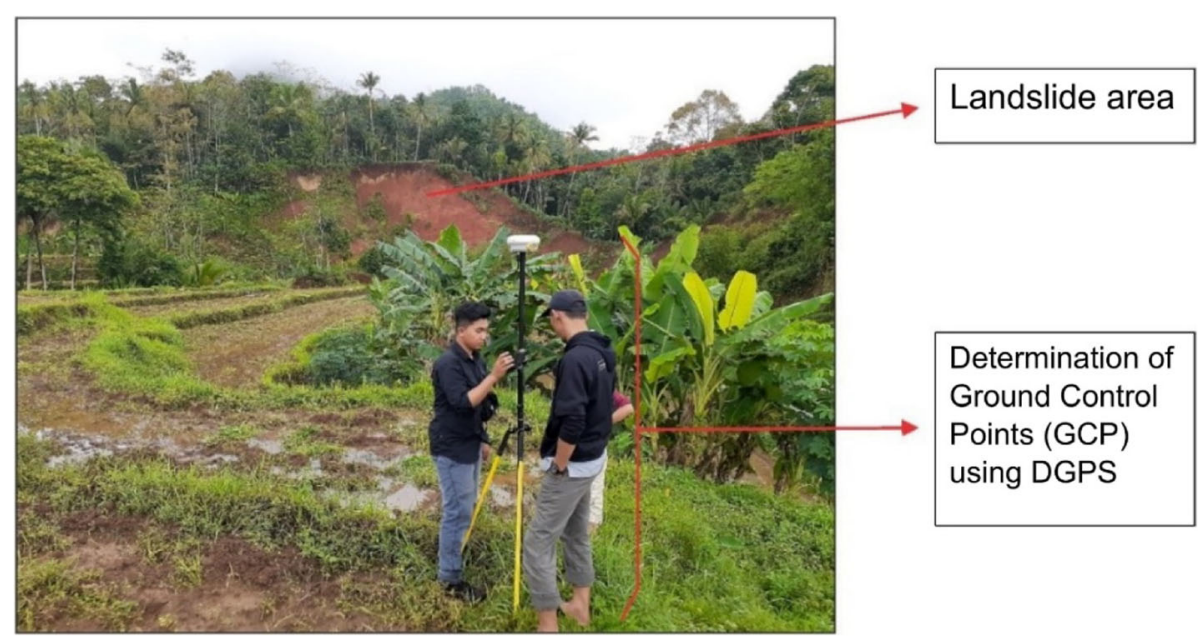

Fig. 2 Measurements of Ground Control Points (GCP) in the research site 


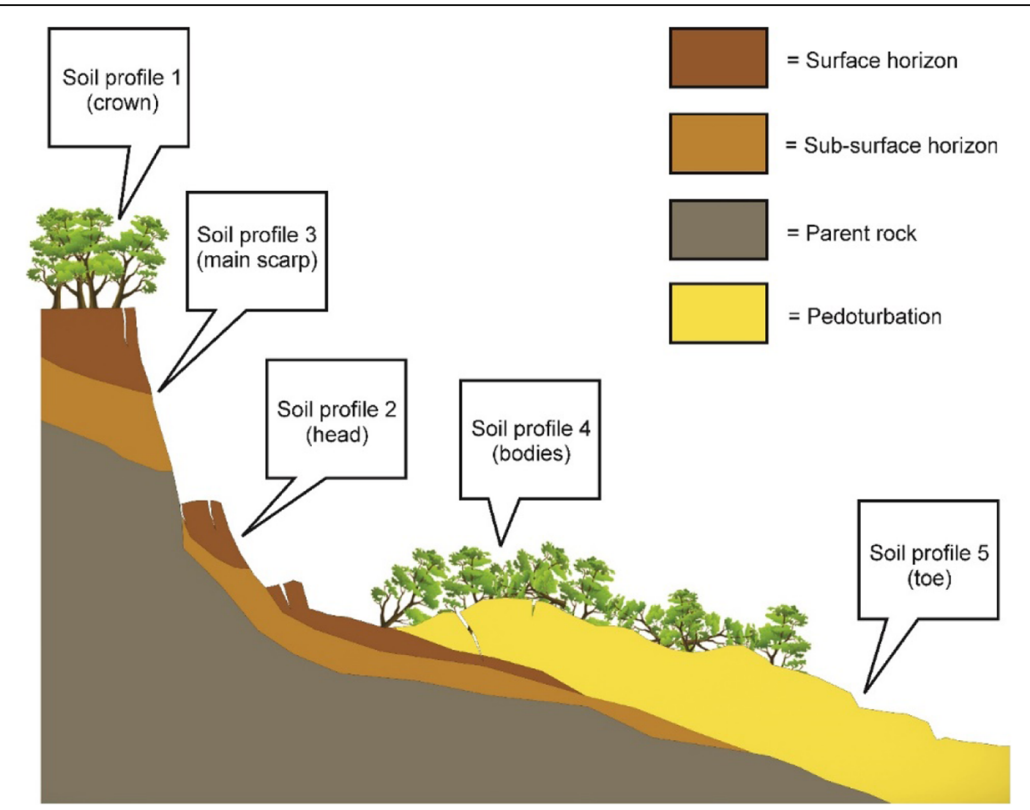

Fig. 3 Illustration of site sampling and design at five landslide parts

\section{Results}

\section{Changes in soil morphological characteristics}

The changes in the soil morphology characteristic as a result of field observation are presented in Table 4 along with the pictures taken during the observation. The pictures are exhibited in discussion section for better description of the results. In addition to that, sketches are also used to explain the phenomena observed in the field.

Soil layer near the surface was developed from new volcanic ash sedimentation that later change into porous soil, while the lower layer was developed from old alterated volcanic rocks. The later one formed less porous soil. The process of eluviations and illuviation on soil profile has caused the formation of genetic $\mathrm{Bw}$ (cambic) in Tegalsari landslide and Bt (argillic) in Wonogiri and Manglong landslide. The original soil in Tegalsari landslide has porous in nature. It is indicated by soil penetration which is less than $1 \mathrm{Kg} \cdot \mathrm{cm}^{-2}$, soil consistency in wet condition which is very loose, volumetric weight of less than $1 \mathrm{~g} . \mathrm{cm}^{-3}$ and soil porosity greater than $55 \%$ (Table 4). Porous soil of Tegalsari has high ability to pass the water with hydraulic conductivity value greater than $25 \mathrm{~cm} \cdot \mathrm{h}^{-1}$. Undisturbed soil in Wonogiri and Manglong landslide contain very high translocated clay and therefore could form cutan clay. Undisturbed soil in Manglong has horizon arrangement of plinthite at 51$65 \mathrm{~cm}$ depth with hydraulic conductivity value less than that of in the horizon above it (Table 4).

Soil in Tegalsari and Manglong has clay content between $50 \%-60 \%$, while soil in Wonogiri has quite high which is close to $90 \%$ (Table 4). In general, the soil in volcanic landscape is thick soil, has many layers and high content of clay (Sartohadi et al., 2018; Wida et al., 2019). The formation of thick soil is due to series of sedimentation of volcanic ash which is later developed to become soil. Volcanic ash has high content of mineral and is easily decomposed to produce clay (Pulungan and Sartohadi, 2018b). The characteristic of soil morphology near the undisturbed surface in Tegalsari has showed the sedimentation of volcanic ash that has not been completely decomposed. It is indicated with clay content of less than $20 \%$ and sand greater than $40 \%$. However, at the depth of more than $240 \mathrm{~cm}$, the clay content reaches more than $60 \%$. The present of clay layer can be found

Table 3 Slope stability classes

\begin{tabular}{lll}
\hline Safety factor $(\mathrm{F})$ & Slope stability class & Remarks \\
\hline $\mathrm{F}>1.5$ & Stable & Only major destabilising factors lead to instability \\
$1.25<\mathrm{F}<1.5$ & Moderately stable & Moderate destabilising factors lead to instability \\
$1<\mathrm{F}<1.25$ & Quasi stable & Minor destabilising factors can lead to instability \\
$\mathrm{F}<1$ & Unstable & Stabilising factors are needed for stability \\
\hline
\end{tabular}




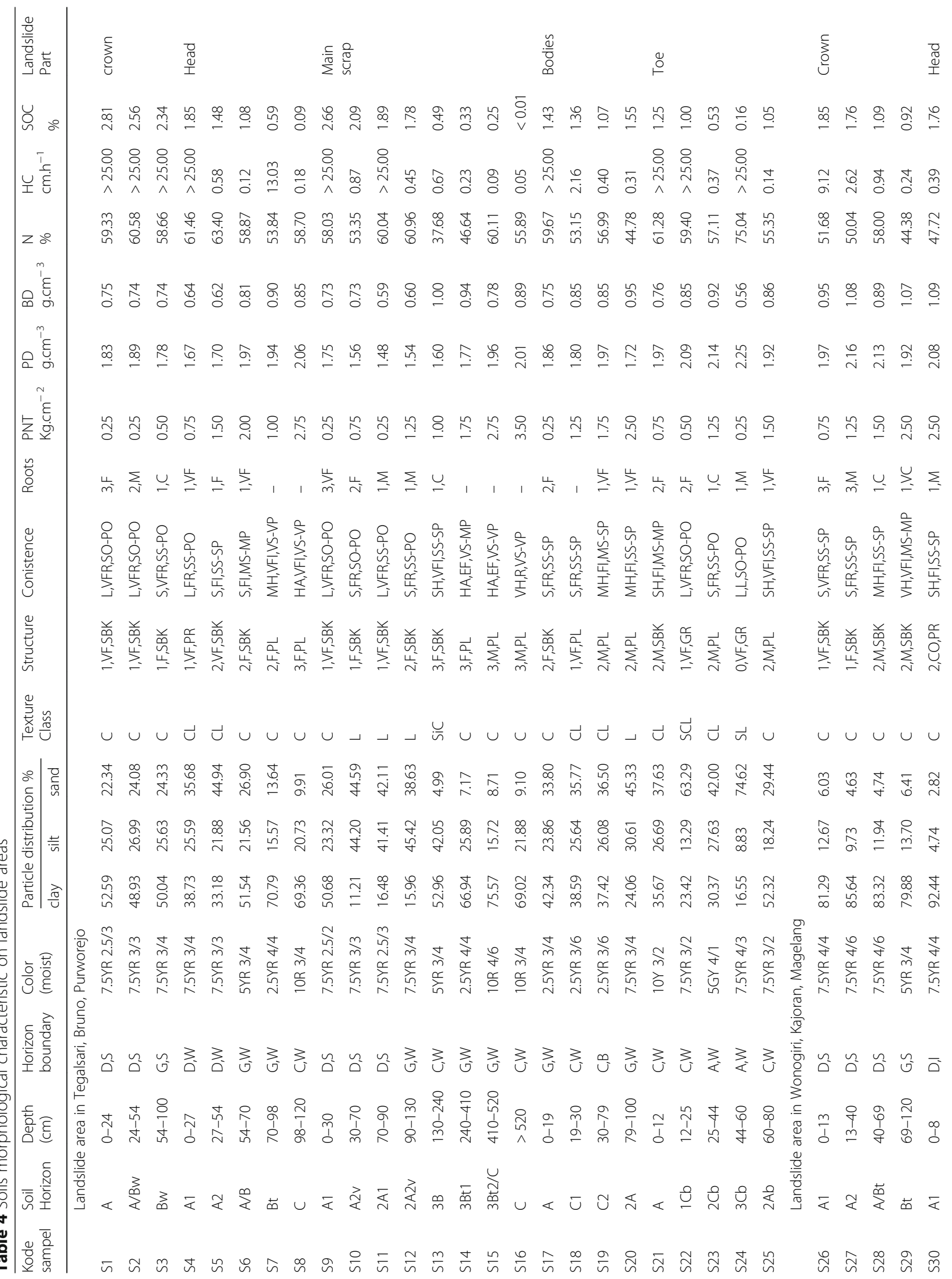




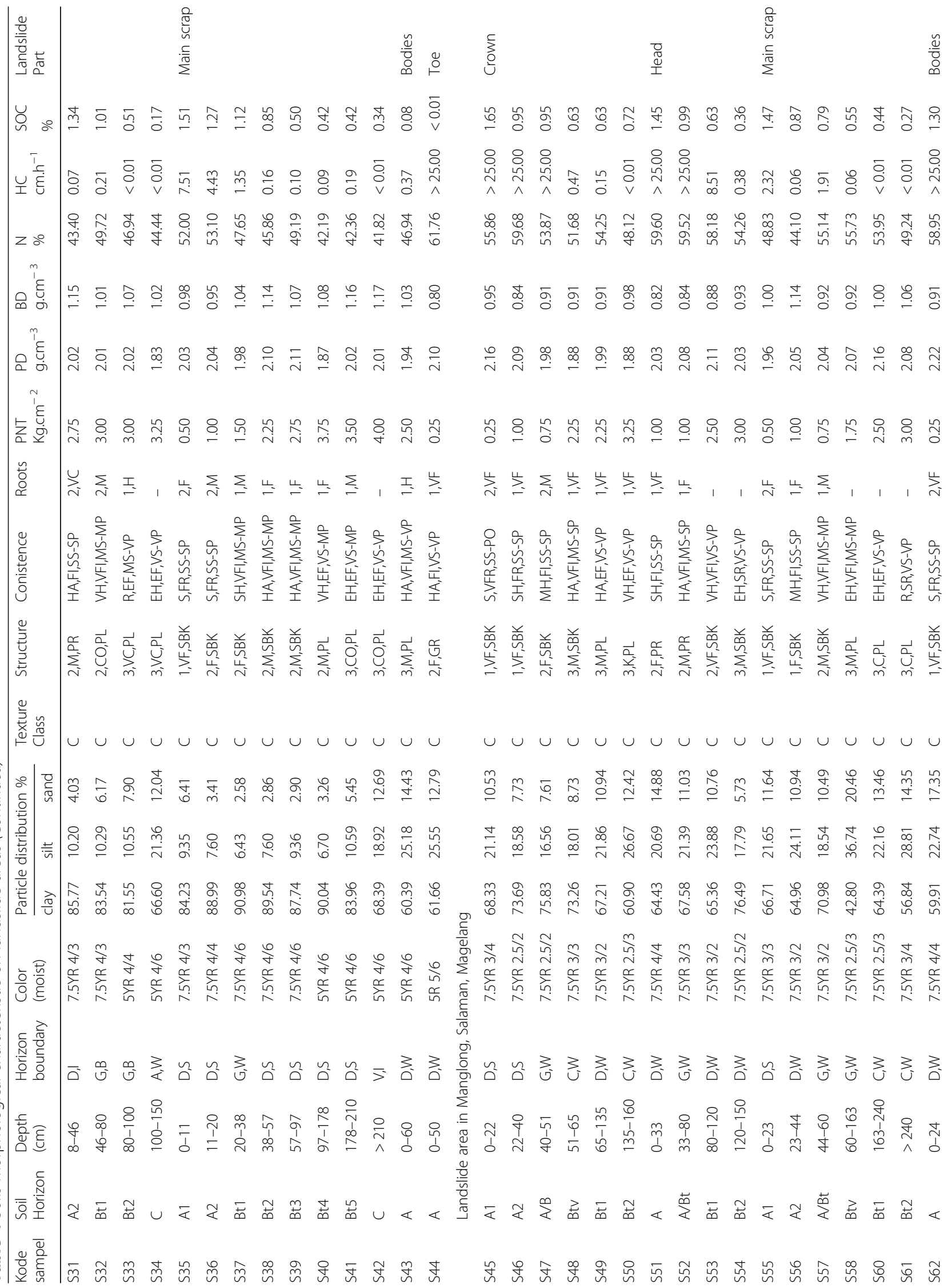




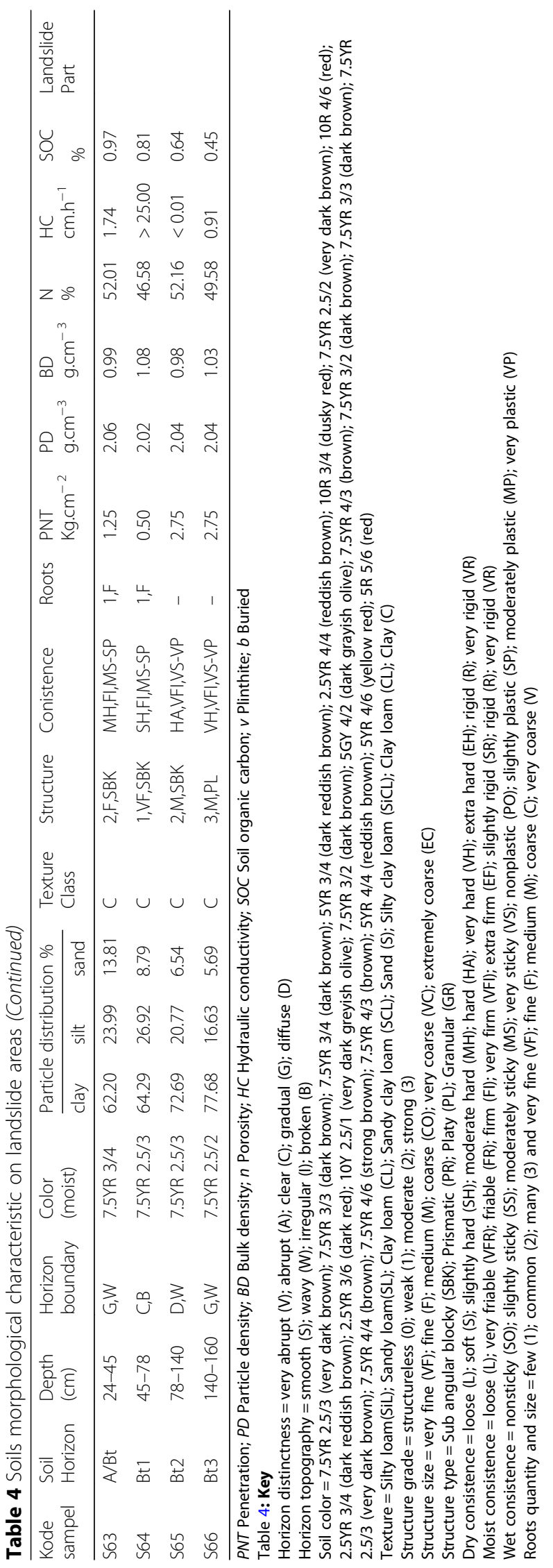


at the depth of more than $200 \mathrm{~cm}$ in all over the land slide study area, with relatively very high content of clay.

Soil layer below the surface with high content of clay is come from old volcanic rocks that have gone through hydrothermal alteration process in the old time (Van Bemmelen, 1949). Alteration of volcanic rocks produces soil with high content of clay with mineral type in the clay that is sensitive towards wetting and therefore has high chance to trigger the landslide (Pulungan and Sartohadi, 2018a).

The head of landslide relatively moves less but it causes the changes in morphological characteristic in the land as well as soil. Micro relief of land surface becomes wavy and some parts irregularly broken. Land horizon arrangement in the head of landslide still completes, however, the physical characteristics parameters of soil have substantially changed. The changes in these parameters relatively easy to be observed (Noviyanto et al., 2017). The thickness of the horizon A decreased spottily due to the influence of surface waving. Little downshifting process on lower layer of soil can cause crack and even damage on the horizon surface. Cracks on the soil surface increases the saturated hydraulic conductivity up to more than $25 \mathrm{~cm} \cdot \mathrm{h}^{-1}$ and change the soil structure to become prismatic. The lower layer of soil also went through compression process due to litho static pressure from the upper soil layer. Lower layer soil compression was indicated with the increase in soil penetration value which is higher than $3 \mathrm{Kg} \cdot \mathrm{cm}^{-3}$ and the change in the soil structure become platy. The findings from landslide study area support and consistent with the observation of material characteristic in various part of landslides done by Cheng et al. (2016).

The changes in soil morphology characteristic in the body and foot of landslide were caused by slides and spread processes that cause disorder in the soil layer. The pattern of changes in the physical and chemical characteristic of soil did not show similarity or regularity in all three landslides that were observed. The pattern in soil morphological changes was more complex in Tegalsari due the addition and subtractions of landslide material from the river that passed through it. The main soil with low content of Corganic appeared in the surface of Wonogiri landslide (Table 4). At the tip of the foot of the Wonogiri landslide, the soil material that slide at the farthest become granular in structure, but it became easily dispersed when it was wet, and therefore can trigger the second landslide. Different condition was found in the foot of Manglong landslide, where the mixed soil material was removed as it blocked the main path and leaves the body landslide with the soil that was not agitated. Soil morphology characteristics in the body of the Manglong landslide still had the complete parts of horizon arrangement, but some physical characteristics have changed such as weight, volume, porosity and saturated hydraulic conductivity.

\section{Vulnerability level of landslide}

Three landslides under the observation are still having potential to reoccur. The analysis of topography indicators that covered slopes, surface roughness index and slope stability was conducted to get more information about the landslide vulnerability in the landslide area (Yu et al., 2017). The outcome shows that the slope with angle greater than $30^{\circ}$ was found in steep portion of Tegalsari and Manglong landslide and at the foot of Wonogiri landslide. While the analysis of surface roughness index shows that landslide deposition possesses heterogenic relief in all zones. The surface roughness index is a topographic indicator that shows spatial variability at the altitude of particular area (Lindsay et al., 2019). This index also has been used widely in the previous researches to describe vulnerability of the landslide (Glenn et al., 2006; Li et al., 2015). The higher that slope angle and surface roughness index, the higher is the vulnerability level of that area (Kang et al., 2019).

The stability level of slope in the land that vulnerable towards landslide can be evaluated through analysis of safety factor (Table 5). The result shows that the unstable slope lies on the steep portion of Tegalsari and Manglong landslide and at the foot of Wonogiri landslide. The distribution of the value of safety factor is proportional with the slope. The steeper, the more unstable is the slope. The unstable slope is also caused by soil characteristics which is very thick and has high content of clay, and it influenced the volumetric weight of the soil, cohesion, and the ability of soil to retain water. The lower the soil cohesion level, the higher is the friction

Table $\mathbf{5}$ Factor of safety and soil moisture content

\begin{tabular}{|c|c|c|c|c|c|c|c|c|c|c|c|}
\hline \multirow[t]{2}{*}{ Location } & \multirow[t]{2}{*}{$\begin{array}{l}\text { Genesis of } \\
\text { clay layer }\end{array}$} & We & C & $\begin{array}{l}Y \\
-3 m^{-3}\end{array}$ & $\mathrm{H}$ & a & $\cos ^{2} a$ & $\begin{array}{l}\text { tana } \\
0\end{array}$ & $\underset{0}{\Phi}$ & $\tan \Phi$ & $F$ \\
\hline & & & & & & & & & & & \\
\hline Tegalsari & Volcanic ash & 54.00 & 68.59 & 9.22 & 7 & 32 & 0.115 & -2.78 & 17.74 & -10.17 & 0.33 \\
\hline Tegalsari & Parent rock & 77.95 & 17.70 & 8.73 & 5 & 32 & 0.115 & -2.78 & 17.24 & 47.30 & -18.30 \\
\hline Wonogiri & Volcanic ash & 45.04 & $15 . s 16$ & 10.59 & 6 & 27 & 0.060 & 3.94 & 56.11 & 1.73 & 1.44 \\
\hline Wonogiri & Parent rock & 36.53 & 8.52 & 11.47 & 5 & 27 & 0.060 & 3.94 & 43.71 & 1.10 & 0.90 \\
\hline Manglong & Volcanic ash & 43.70 & 13.33 & 10.40 & 15 & 19 & 0.003 & -17.24 & 37.92 & -26.31 & 0.05 \\
\hline
\end{tabular}

Note: Wc Soil moisture content; $F$ Safety factor 
angle, and the easier for the landslide to occur. Furthermore, clay layer from decomposed volcanic ash has safety factor which is higher than that of decomposed master tuff rock and alterated breccia rock. It was found in all of area under study that slopes are not stable $(\mathrm{F}<$ 1) except the one in Wonogiri landslide which has medium slope stability (Table 5).

\section{Discussion}

\section{Changes in soil morphological characteristics}

Undisturbed soil in the crown of the landslide showed complete horizons. Soil at the surface was formed from series of volcanic ash sedimentation that contain high mineral. It decomposes in relatively short time produces thick soil with high content of clay particles (Pulungan and Sartohadi, 2018b). The development of land from volcanic ash under humid tropical climate is characterized with the formation of horizon B which has higher clay compared with the horizon lays over it (Pal et al., 2014). The soil in the Tegalsari landslide area is characterized with the existence of horizon Bw (see Fig. 4a) and the soil two other landslide locations is characterized with the existence of horizon Bt (see Fig. 4b and c). Horizon Bw and Bt differ in term of the increase in the content of clay compared with the horizon lays over it. Horizon Bt has an increase of clay content which is relatively higher $(10 \%-$ $20 \%$ ) compared with the horizon Bw (Table 4 column 5 , S3, S29, S49).

Undisturbed soil in Tegalsari landslide location has soil development level lower than undisturbed soil in other two locations. The difference in the soil development level was possible due to the difference in the type of base rocks that have different capacity in passing the water (Table 4 column 16). Soil in Tegalsari was developed above tuffacious sandy rocks that have been decomposed, and therefore the movement of water in soil profile up to $2 \mathrm{~m}$ depth have not produced distinct increase in clay content (Table 4 column 5, S1-S3). Soil in Wonogiri ad Manglong was developed above breccia rocks that have gone through alteration and therefore has compressed characteristic and can result in the increase of clay content at the depth of less than $2 \mathrm{~m}$ (Table 4 column 5, S26- S29, S45-S50). The evaluation at the soil development level was done only for soil profile at maximum of $2 \mathrm{~m}$ depth (Schoeneberger et al., 2012).

Undisturbed soil at all landslide locations has high capacity in passing the water (Table 4 column 17, S1, S26, S45). The soil has relatively high content of clay and organic matters, and therefore it formed stable soil structure (Johannes et al., 2017). The rain water that fall in the soil surface will be immediately absorbed in the soil profile make the all soil horizon wet. The existence of horizon Bt has important role in landslide study (Sartohadi et al., 2018). Horizon Bt will act as sliding plane as because of the following physical characteristics: (1) low ability to pass water (Table 4 column 17, S29, S49, S50) (2) soil that easily dispersed (muddy when it is wet).

Escarpment of landslide showed soil profile and layers of soil material lying under. (Fig. 5). The term of soil profile is used to describe horizons which was formed through pedogenic process at up to $2 \mathrm{~m}$ depth (Schaetzl and Anderson, 2005), while layer terminology is used to describe the difference in soil material at the depth of more than $2 \mathrm{~m}$ (Sartohadi et al., 2018). Soil layers with high content of clay also found at the depth of more than $2 \mathrm{~m}$ in all landslide location under study (Table 4 column 6 , S14-S16, S42, S61). The existence of soil material layers with high clay content has different origin: (1) at Tegalsari landslide location, it was formed as a result of deep
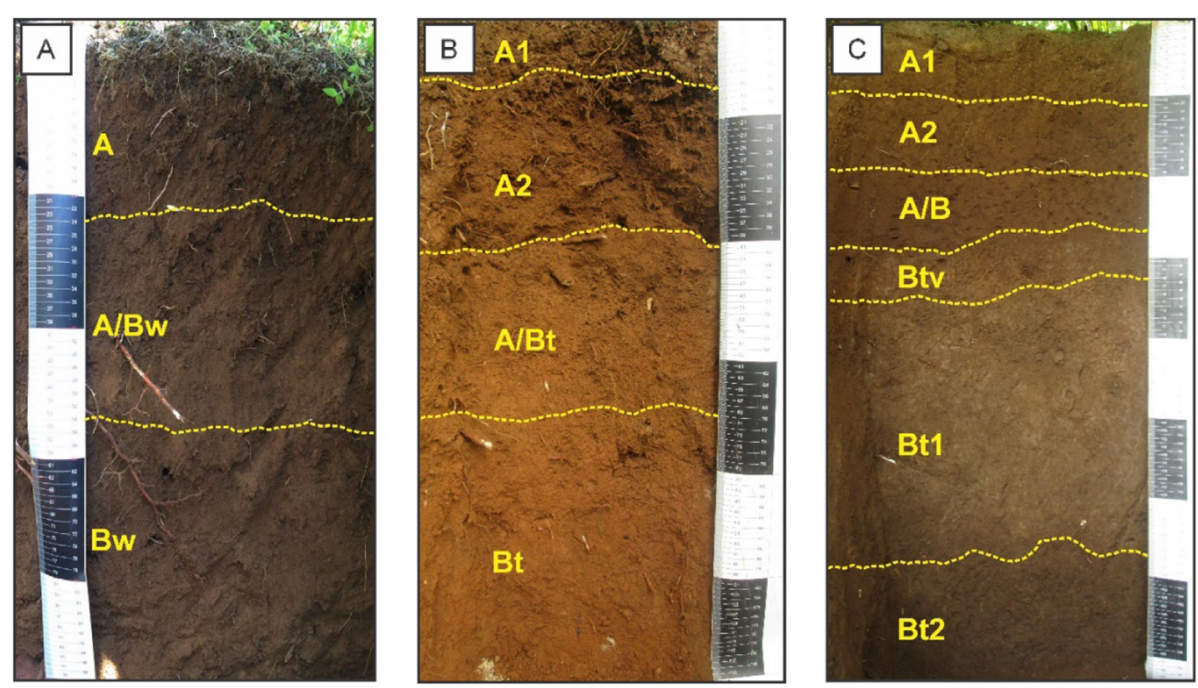

Fig. 4 Types of soil genetic horizon on crown part of landslide area: Tegalsari (a), Wonogiri (b), and Manglong (c) 

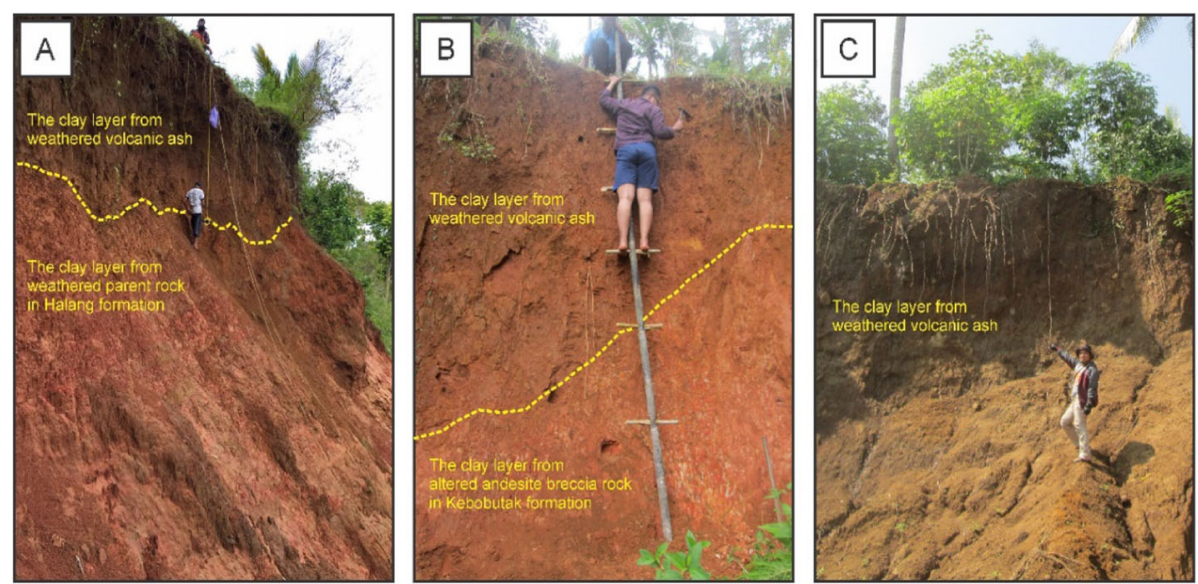

Fig. 5 Soil and weathered rock materials in the main scraps of: Tegalsari (a), Wonogiri (b) and Manglong (c)

translocation of clay from layers lay over it, (2) at the Wonogiri landslide location, it came from base rocks after hydrothermal alteration in the past, (3) at the Manglong landslide location, it was formed from repeated formation process (polygenetic soil formation). Whether it is horizon Bt at less than $2 \mathrm{~m}$ depth or soil material layers at more than $2 \mathrm{~m}$ depth, both can act as landslide sliding plane in the wet conditions.

The soil horizons and soil material layers which are exposed to landslide fault escarpment describe the physical and chemical characteristics of soil particle that form them in various ways. Soil horizons are developed from parent soil of recent volcanic ash, while soil material layers are developed through different types of processes. Soil material layers in Tegalsari landslide were developed tuffacious sandy rocks, while the one in Wonogiri was developed from hydrothermal alteration material in the past that came into contact with volcanic breccias. Only soil material layers in Manglong landslide was developed from old volcanic ash. Landslide causes down-slope movement of all soil particles with different physical and chemical characteristics (Szokoli et al., 2018) with various intensity. The different in intensity of down-slope movement results in unique land surface morphology and specific agitation level of soil materials.

Soil morphology and arrangement of horizons at the head of landslide did not change much in the context of the variety of horizons (see Fig. 6). Morphological change of soil occurred in the thickness of the horizons followed by physical characteristics such as colour and clay content (Table 4 column 5 and Column 6, S4-S8, S30-S34, S51-S54). The change in the horizon thickness
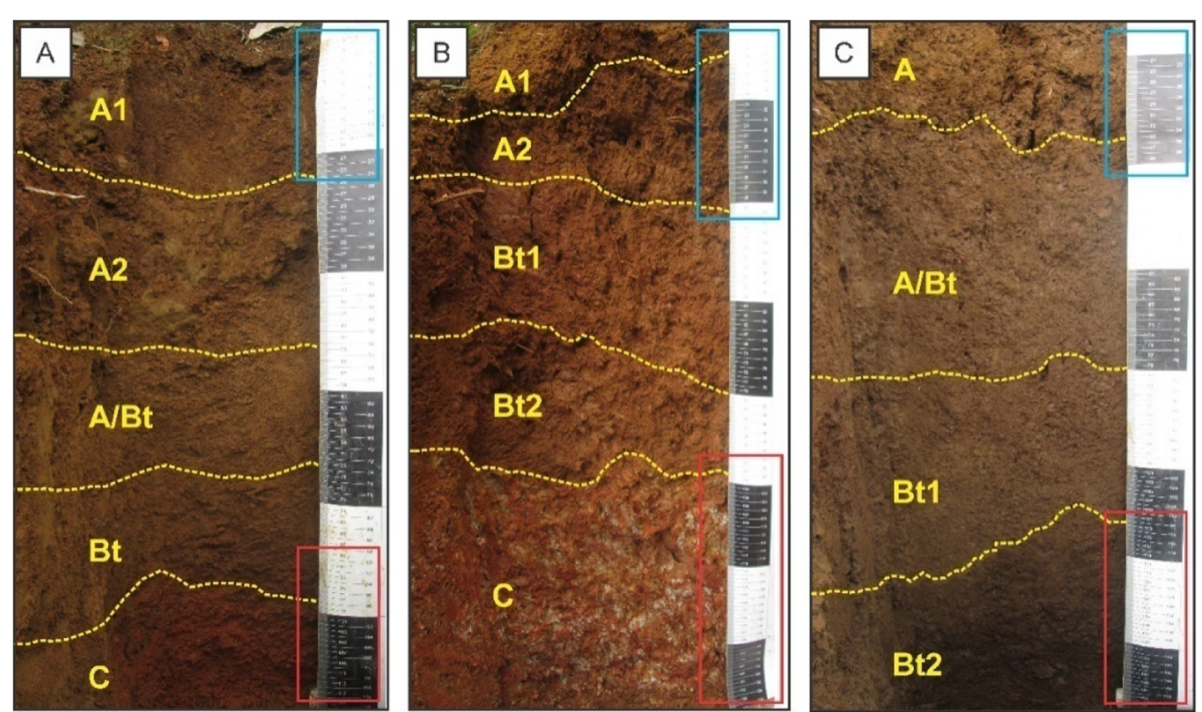

Fig. 6 Soil morphology on the head part of landslide: Tegalsari (b), Wonogiri (b), and Manglong (c). The blue lines show cracking and difference of soil structure (type of prismatic). The red lines show lithostatic pressure 
was thought as a result of compaction, limited mixing and lessening. Compaction process happened due to the vertical movement and thus resulting in the compression (Table 4 column 13 and column 17, S8, S34, S54). Different process of limited mixing between soil horizon and/or soil material layers were found in three landslide points under study. Mixing at horizon 3Bt1 happened at the escarpment with the soil material horizon/other layers to form horizon $\mathrm{A} / \mathrm{B}$ at the head of landslide at Tegalsari which is characterized by the decrease of clay content from $66.94 \%$ to $51.54 \%$. Similar thing happened at landslide Wonogiri where horizon Bt4 at escarpment with clay content $90.04 \%$ changes into horizon Bt1 at the head with clay content of $83.54 \%$. While horizon A/ Bt1at escarpment of Manglong landslide with clay content $70.98 \%$ changed into horizon Bt1 at the head with clay content $65.36 \%$.

Lessening process occurred at the soil horizons in escarpment with less than $1 \mathrm{~m}$ depth as a result of sliding to the landslide part at the lower position. Part by part sliding of soil horizon occurred due to minor sliding plane that further caused the soil layers at the upper part slide farther than the lower soil layer (see Fig. 7). Horizon A that has been observed at the head, most probably came from the debris of soil material from escarpment.post major landslide move. The changes in the thickness of horizon A at the head in comparison with those at the escarpment is shown in Table 4 (column 3, S9, S35, S56).

Changes of soil morphology at the body have been found different in the three landslide points under observation. The difference was due to specific type and movement intensity in every location under study. The change of soil morphology at Wonogiri landslide body (S43) was as a result of turn over process of layers due to landslide movement at lower layer (at the depth of horizon $\mathrm{Bt}$ ). It was proved with the similarity in colour (5YR 4/6, yellow red) and clay content $(60 \%-70 \%)$ which is similar to clay layer at alterated volcanic rocks
(S42) at the escarpment. The changes of soil morphology at the Manglong landslide body was due to accumulation process of material at soil surface horizon, which was characterized with C-organic content which is higher than $1 \%$ and more porous (58.95\% porosity) and hydraulic conductivity greater than $25 \mathrm{~cm} . \mathrm{h}^{-1}$. In the meanwhile, the changes of soil morphology at Manglong landslide body cannot be explained the way the changes at Wonogiri and Tegalsari were explained, as the landslide at Manglong occurred long before the observation was conducted. The changes of soil morphology are illustrated based on landslide movement that occurred (see Fig. 8).

Figure 9a of soil profile at the Tegalsari landslide body shows there is mixing and turnover of soil layers in escarpment. An appearance similar to rocks fragment was chunks of soil materials which came from soil layers at depth of 2-4 m at escarpment. Figure 9b shows soil profile at Wonogiri landslide body which came from soil material at the depth of more than $2 \mathrm{~m}$ at the escarpment. While Fig. 9c shows soil profile at Manglong landslide body that is relatively similar to arrangement and soil layers at the escarpment. The landslide that occurred in Manglong involved only series of soil layers that came from volcanic ash and did not reach layer which was a result of volcanic rocks decomposition. Horizon notations in Fig. 9c is similar to landslide at the escarpment, but it has higher clay content (more than 70\%) at the body compared with that in escarpment (less than 70\%). So it did not come from layer with the same notation in escarpment

Soil morphology at the foot of landslide can be explained only based on the observation conducted at the Tegalsari and Wonogiri landslide. Soil morphology at the foot of landslide of Tegalsari (Fig. 10a) has physical characteristics which quite different with the ones of the landslide at the upper portion of it. Most probably it was as a result of sedimentation at nearby river. Soil morphology at the foot of the landslide was a result of turn over process

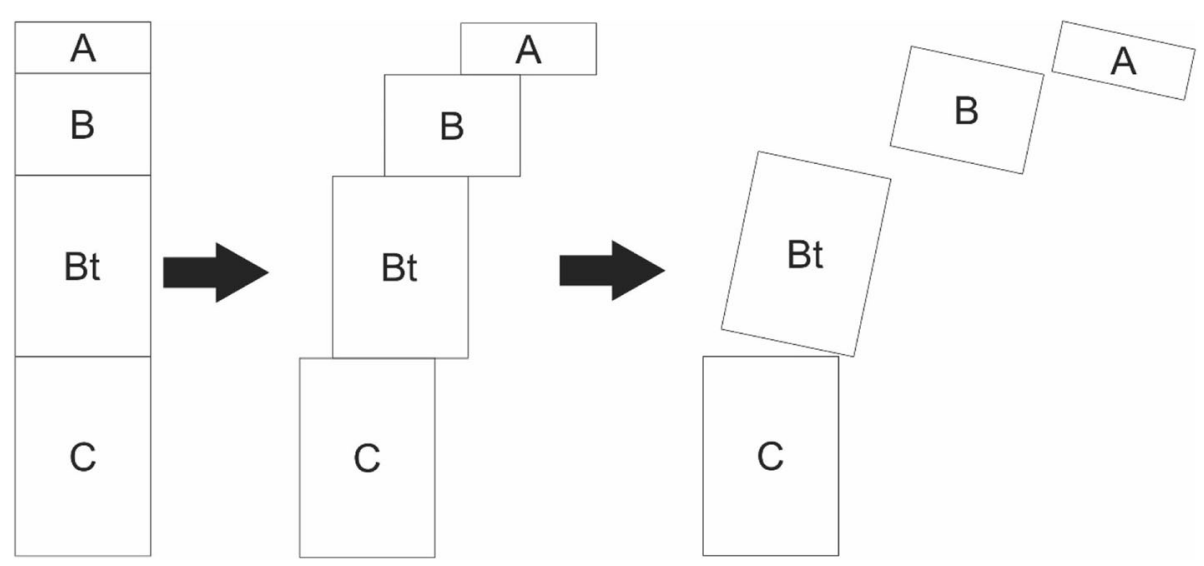

Fig. 7 Illustration of soil layer arrangement at the head part as a result of landslide movement process 

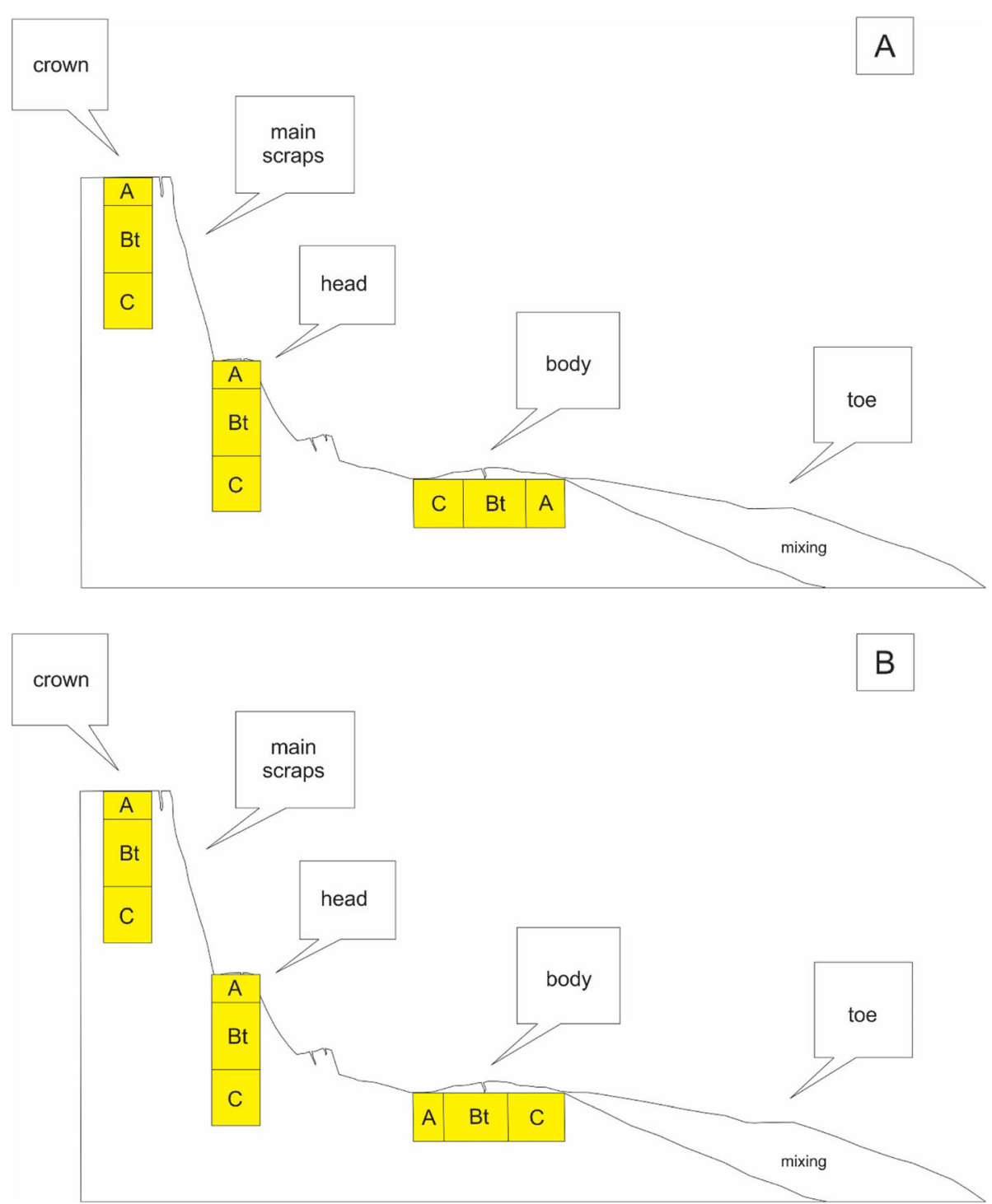

Fig. 8 Illustration of landslide movement that caused changes at landslide body; (a) Rotational movement; (b) Topping Movement

of soil layers at the escarpment (Fig. 10b). Layer of clay soil (S41 and S42) at the escarpment became soil surface at the foot of the landslide. The soil has the following characteristics: tends to have red in colour (5R 5/6, red), very low organic content (less than $1 \%$ ) and high clay content (more than 60\%). It shows that the layers at the surface was as a result of turnover of volcanic ash layers which was further decomposed (S41) and alterated volcanic (S42). Soil morphology at the foot of Wonogiri landslide is a water saturated zone which was proved with low level of penetration $\left(<0.5 \mathrm{Kg} . \mathrm{cm}^{-2}\right)$, high hydraulic conductivity $\left(>25 \mathrm{~cm} \cdot \mathrm{h}^{-1}\right)$ and high porosity level $(>60 \%)$.

Sedimentation of soil materials at the foot of the landslide will change according to the process and intensity of disturbances. Disturbance such as flood will change the shape and composition where soil materials from landslide will be taken away replaced with other material. Over flow from flood causes water saturation at the landslide deposition zone, and therefore will have more reactive soil mechanic characteristics. Other disturbance is from human activities, where soil material sedimentation will disappear or will be utilized further. Loose soil material is good and can be used for agriculture purpose for the surrounding people. Since the disturbance happened at the foot of the landslide, the characteristics of soil morphology at this part cannot be formulated with certainty for long term period.

The process of soil turn over that occurred at the body and toe of landslide is different with the one that happened due to pedogenetic process. The turn over soil that happened due to pedogenetic process generally found as 

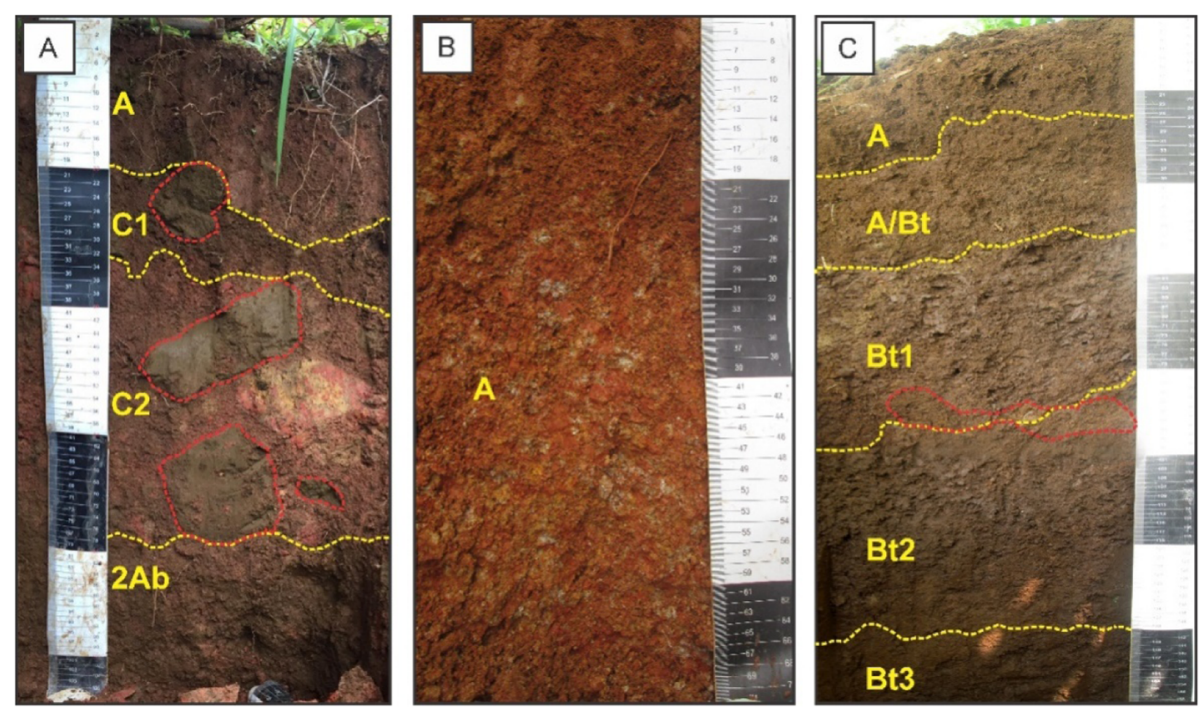

Fig. 9 Soil morphology on the bodies parts of landslide: Tegalsari (a), Wonogiri (b), and Manglong (c). Note: Red lines show boundaries of broken horizon. Soil profile in Wonogiri shows pedoturbated horizon

pedoturbation such as in Vertisol soil (Pal et al., 2012). Pedoturbation occurs at the flat land or basin (Pierre et al., 2019). Turn over process can also occur due to pedobioturbatic, both due to flora or fauna (Ruiz et al., 2015; Piron et al., 2017). Bioturbatic process is local and with small area (Whitesides, 2015; Román-sánchez and Reimann, 2019). Pedoturbation of landslide process occurs at the sloped area with the area bigger than that of bioturbatic. Pedoturbation at the landslide involve not only layers turn over, but also other process such as compaction, gravitational mixing and lateral lessening. Gravitational mixing has been explained by Cheng et al. (2016) and Van Eynde et al. (2017), however, in this research, more detail explanation is put on with the presentation of soil morphology characteristics in every part of the landslide. Lessening process in the landslide under study is also different with the process explained by
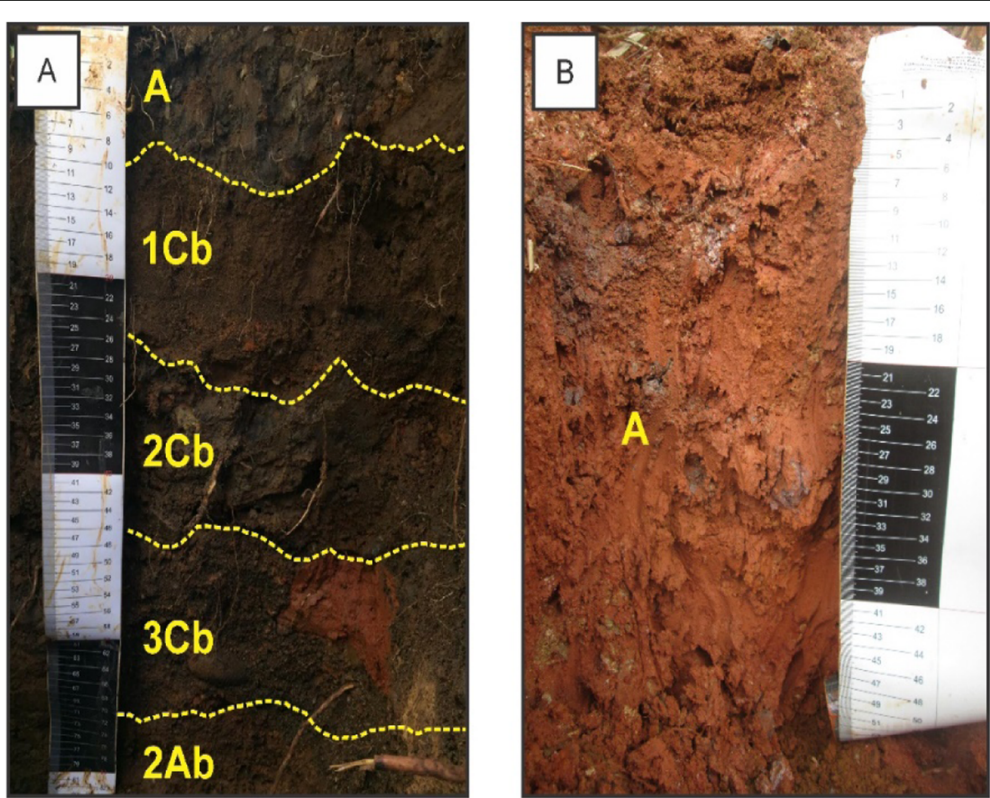

Fig. 10 Soil morphology on toe parts of landslide: Tegalsari (a) and Wonogiri (b). Note: Soil profile in Tegalsari shows superposition of mass movements and rock fragments. Soil profile in Wonogiri shows pedoturbated horizon 
(Mhazo et al., 2016). Lessening process in erosion covers particle by particle, while in landslide covers whole horizons and even whole soil profile.

\section{Vulnerability level of landslide}

Rain fall is the main factor that triggers the slope failure in the region with tropical humid climate. Slope failure usually is caused by the increase in the water content and pore water pressure that further reduce the ground shear strength (Malizia and Shakoor, 2018). The increase in the soil water content results in the increase of the volumetric weight of soil and shear stress, while effective stress will decrease (Chae et al., 2015). Combination between shear stress and slope angle will result in bigger force towards the slope. Mechanically, ground has maximum shear resistance that can be used against the external force that can damage the soil physically. Landslide is a result of condition where the ground cannot bear the force from huge shear stress. Characteristic and property of soil play important role in bearing the force, where in this case, the soil with high content of clay has sensitive characteristic. Sensitivity of clay properties is influenced by soil water content, where the increase in sensitivity will cause high level of landslide vulnerability. Figure 11 exhibits the outcome of triaxial test of soil with high content of clay.

High water content soil was found in the clay layer from decomposed tuffacious sandy rocks at Tegalsari landslide, and this condition can cause negative value in safety factor (Cheng and Lau, 2014). In reverse, low water content soil at Wonogiri landslide results in relatively higher safety factor, even though the clay content is quite extreme. Safety factor (F value) in the clay layers from decomposed volcanic ash at Wonogiri landslide is 1.44 , and therefore is classified as a stable slope. However, alterated andesite breccias rock which was laid under decomposed volcanic ash will make slope even more prone of landslide, and it was proven with the safety factor ( $\mathrm{F}$ value) less than 1 . Chloric mineral is a product of hydrothermal alteration and therefore can be found in alterated rocks (Pirajno, 2009). This mineral is typical silicate mineral 2:1 that can easily shrink or expand (Schaetzl and Anderson, 2005), and this cause the clay layers in alterated andesite rocks become more sensitive and unstable. Slope failure was found in Manglong landslide with $F$ value 0.05 . One of the minerals in volcanic ash such as Na-plagioclase might be found in the clay layer on Manglong landslide. Sodium in the clay layer can act as dispersing agent when the water content increase.

\section{Implication for rehabilitation post landslide}

The change in soil morphology at the body of the landslide tends to form soil that sensitive towards erosion. The sensitivity is due to unstable soil structure (structure hardness degree is weak and soil penetration is less than 0.5 ). The change in soil surface morphology at the body of the landslide produced complex reliefs (Fig. 12b and $h$ ). There exist some parts with steep but short slope. Combination between soil morphology and soil surface morphology, added with position at escarpment and body of the landslide cause the plots formation of erosion become more intensive (Hassen and Bantider, 2020). Figure 13 shows example of the surface of the body of landslide in Manglong where many plots and trenches erosion can be seen. If it is not controlled, plots and trenches can initiate the process of landslide reactivation. It is supported by the observation of safety factor (Fig. 12c, f and i).

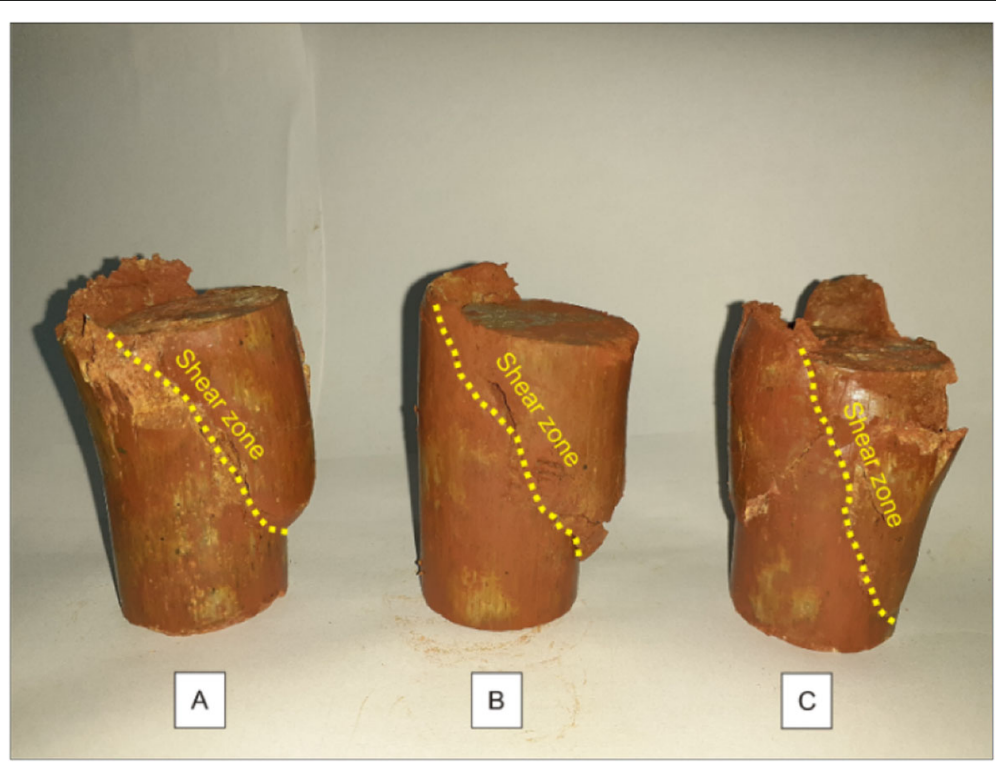

Fig. 11 The results of a triaxial test for high clay layers. Note: $\sigma^{1}=98.0665 \mathrm{kN} \cdot \mathrm{m}^{-2}(\mathbf{a}) ; \sigma^{2}=137.293 \mathrm{kN} \cdot \mathrm{m}^{-2}(\mathbf{b}) ; \sigma^{3}=176.52 \mathrm{kN} \cdot \mathrm{m}^{-2}(\mathbf{c})$ 


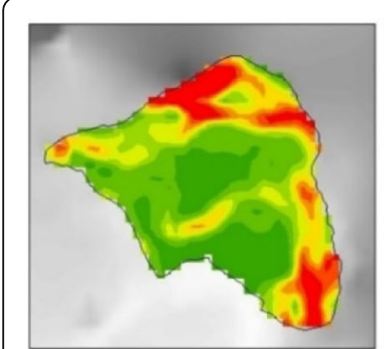

(a)

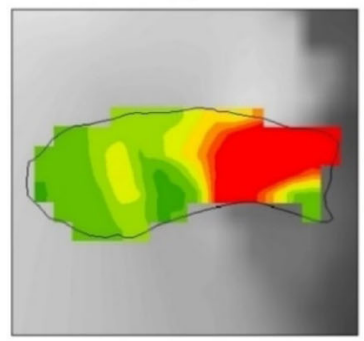

(d)

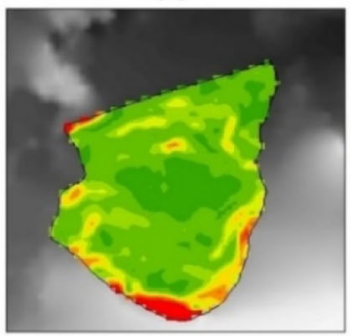

(g)

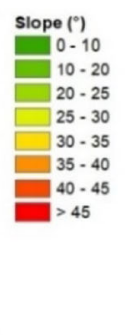

Slope (")
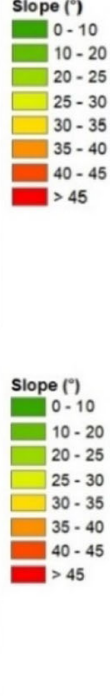

Slope $\left({ }^{\circ}\right)$
$0-10$
$10-20$
$20-25$
$25-30$
$30-35$
$35-40$
$40-45$
$>45$

graphir Tegalsari; (b) terrain ruggedness index in Tegalsari; (c) safety factor in Tegalsari; (d) slope angle in Wonogiri; (e) terrain ruggedness index in Wonogiri; (f) safety factor in wonogiri; (g) slope angle in Manglong; (h) terrain ruggedness index in Manglong; (i) safety factor in Manglong
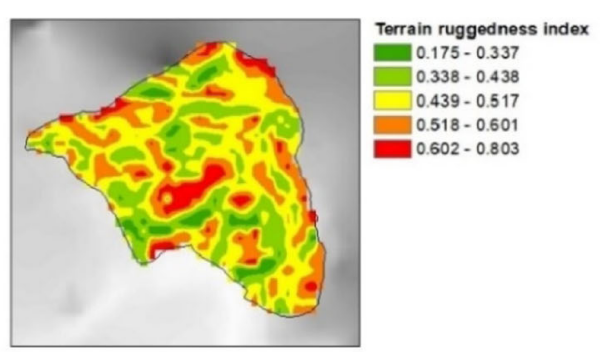

(b)

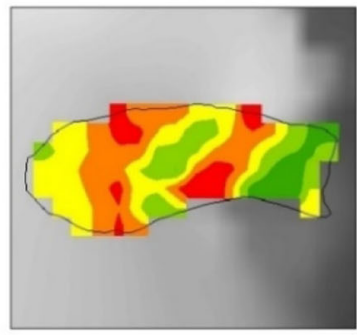

Terrain ruggedness index Terra in ruggednes
$0.250-0.384$
$0.385-0.469$ $0.385-0.469$
$\square$
$0.470-0.530$ $0.531-0.592$ $0.593-0.705$

(e)

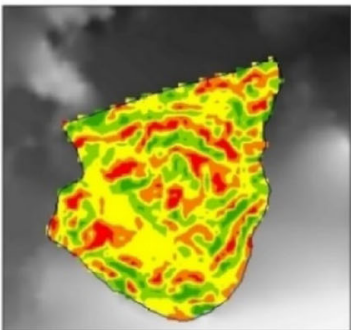

(h) $0.199-0.383$

$0.384-0.457$

$0.458-0.522$

$0.523-0.591$
$0.592-0.770$

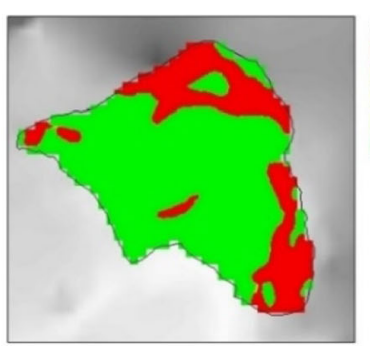

Safety factor $<1.00$
$1.00-1.25$
$1.25-1.50$ $1.25-1.50$
$1.50-2.00$ $\square>2.00$

(c)

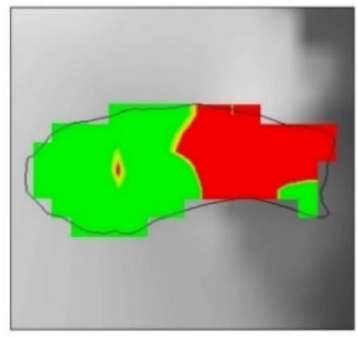

Safety factor

- $<1$

$1.00 \cdot 1.25$ $\square 1.25-1.50$ $1.50 \cdot 2.00$ $>2.00$

(f)

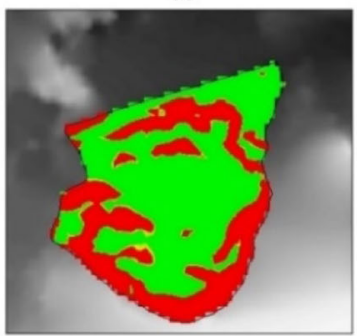

Safety factor

$1<1$

(i)

$1.00-1.25$

$1.25-1.50$

$1.50 \cdot 2.00$

$>2.00$

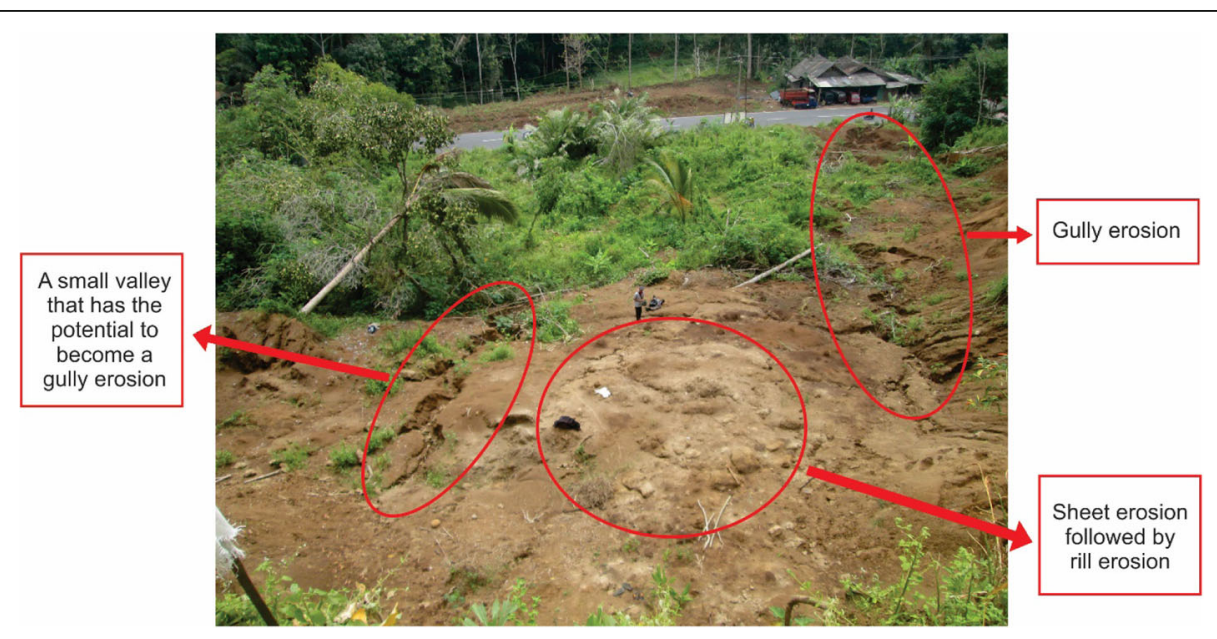

Fig. 13 The appearance of erosion in landslide sediments 
Landslide rehabilitation need to take into account the characteristics and properties of soil in every part of the landslide. Soil material from the surface with relatively dark in colour and loose indicates the fertility of the soil for agriculture purpose (C-organic $>1 \%$ and porosity between $50 \%$ - 60\%). Vegetative debris rehabilitation of landslide shall start from foot, body and to the head of landslide in all points that has soil relatively dark in colour and loose. At the foot part, the soil is always wet, thus the vegetative rehabilitation shall be conducted using plants that have high ability in evaporating the water. Plantation at the foot means for reducing the risk of soil will be muddy and move, and thus landslide reactivation can be avoided. Soil at the body of landslide has property of prone towards erosion and therefore the plants that can function as ground cover are required to reduce erosivity of rain and at the same time can increase the organic matters level of soil. In the meanwhile, the soil at the head shows same characteristics with the ones at the crown, thus it requires same type of plants for rehabilitation in the crown of the landslide.

\section{Conclusion}

High thickness of soil and high content of clay along with the angle of the slope play important role in determining landslide sensitivity. Landslide sliding plane at less than $2 \mathrm{~m}$ depth when there is horizon $\mathrm{Bt}$, while landslide sliding plane also found at the depth of more than $2 \mathrm{~m}$ when there is soil material layers with high content of clay. Landslides process at the volcanic soil which is very thick with high content of clay is complex due to multiple landslide slope. Reactivation of landslide is possible to occur at the escarpment and head which is triggered by the angle of the slope and the difference in the elevation which is very high. Landslide reactivation is also can be started from the body and foot which is triggered by the soil characteristics such erodibility and the hardness of land surface. Vegetative landslide rehabilitation can be done by considering the characteristics and properties of soil in every part of the landslide along with the characteristic of the slope. The utilization of land post landslide that does not consider morphological characteristic of land surface can add complexity in the process of land rehabilitation.

\section{Acknowledgements \\ The authors would like to thank Gadjah Mada University for the research and publication funding given to the Thesis Recognition Program Year of 2019 under contract number of 2127/UN1/DITLIT/DIT-LIT/LT/2019. The authors were also thankful to the research group of TRANSBULENT (Transition of Natural Systems in the Built-up Environment) for their discussions and suggestions.}

\section{Authors' contributions}

AN carried out field investigation, laboratory work, and data collection, as well as wrote the manuscript. JS participated in the developing research concepts, edited the manuscript, contributed to the field study and contributed to the manuscript. BHP supervise the research analysis and edited the manuscript. All the authors read and approved the final manuscript.

\section{Funding}

This research was part of the "Management of landslide-prone land resources in the transitional landscape zone between quarternary Sumbing Volcano and tertiary Kulonprogo Volcano" project funded by Gadjah Mada University, Yogyakarta.

\section{Availability of data and materials}

The dataset supporting the conclusions of this article is included within the article.

\section{Competing interests}

The authors declare that they have no competing interest.

\section{Author details}

${ }^{1}$ Master Program in Soil Science, Universitas Gadjah Mada, Yogyakarta, Indonesia. ${ }^{2}$ Department of Soil Science, Universitas Gadjah Mada, Yogyakarta, Indonesia.

Received: 4 September 2019 Accepted: 24 July 2020

Published online: 11 September 2020

\section{References}

Candraningrum ZR (2017) Hubungan mikrorelief dengan karakteristik fisik material tanah permukaan di wilayah longsor aktif (Kasus longsor besar di Desa Margoyoso, Kecamatan Salaman, Kabupaten Magelang, Provinsi Jawa Tengah). Gadjah Mada University. Retrieved from http://etd.repository.ugm. ac.id/index.php?mod=penelitian_detail\&sub=PenelitianDetail\&act=view\&typ= html\&buku_id=110330\&obyek_id $=4$

Chae BG, Lee JH, Park HJ, Choi J (2015) A method for predicting the factor of safety of an infinite slope based on the depth ratio of the wetting front induced by rainfall infiltration. Nat Hazards Earth Syst Sci 15:1835-1849. https://doi.org/10.5194/nhess-15-1835-2015

Cheng CH, Hsiao SC, Huang YS, Hung CY, Pai CW, Chen CP, Menyailo OV (2016) Landslide-induced changes of soil physicochemical properties in Xitou, Central Taiwan. Geoderma 265:187-195. https://doi.org/10.1016/j.geoderma.2015.11.028

Cheng YM, Lau CK (2014) In: CRC Press Taylor \& Francis Group (ed) Slope stability analysis and stabilization ISBN: 978-1-4665-8284-2

Glade T, Crozier MJ (2010) Landslide geomorphology in a changing environment. Geomorphology 120:1-2. https://doi.org/10.1016/j.geomorph.2009.09.018

Glenn NF, Streutker DR, Chadwick DJ, Thackray GD, Dorsch SJ (2006) Analysis of LiDAR-derived topographic information for characterizing and differentiating landslide morphology and activity. Geomorphology 73:131-148. https://doi. org/10.1016/j.geomorph.2005.07.006

Gylland AS, Rueslåtten H, Jostad HP, Nordal S (2013) Microstructural observations of shear zones in sensitive clay. Eng Geol 163:75-88. https://doi.org/10.1016/j. sssenggeo.2013.06.001

Hadmoko DS, Lavigne F, Sartohadi J, Hadi P, Winaryo (2010) Landslide hazard and risk assessment and their application in risk management and landuse planning in eastern flank of Menoreh Mountains, Yogyakarta Province, Indonesia. Nat Hazards 54:623-642. https://doi.org/10.1007/s1 1069-009-9490-0

Hassen G, Bantider A (2020) Assessment of drivers and dynamics of gully erosion in case of Tabota Koromo and Koromo Danshe watersheds, South Central. Geoenvironmental Disasters 7(5):1-13. https://doi.org/10.1186/s40677-019-0138-4

Johannes A, Matter A, Schulin R, Weisskopf P, Baveye PC, Boivin P (2017) Optimal organic carbon values for soil structure quality of arable soils. Does clay content matter? Geoderma 302:14-21. https://doi.org/10.1016/j.geoderma.2017.04.021

Kang K, Ponomarev A, Zerkal O, Huang S, Lin Q (2019) Shallow landslide susceptibility mapping in Sochi ski-jump area using GIS and numerical Modelling. Int J Geo Inform 8:148-163. https://doi.org/10.3390/ijgi8030148

Li X, Cheng X, Chen W, Chen G, Liu S (2015) Identification of forested landslides using LiDar data, object-based image analysis, and machine learning algorithms. Remote Sens 7:9705-9726. https://doi.org/10.3390/rs70809705

Lindsay JB, Newman DR, Francioni A (2019) Scale-optimized surface roughness for topographic analysis. Geoscience 9(7):322-337. https://doi.org/10.3390/ geosciences 9070322

Maeda H, Sasaki T, Furuta K, Takashima K, Umemura A, Kohno M (2012) Relationship between landslides, geologic structures, and hydrothermal 
alteration zones in the Ohekisawa-Shikerebembetsugawa landslide area, Hokkaido, Japan. J Earth Sci Eng 2:317-327. https://doi.org/10.17265/2159$581 X / 2012.06 .001$

Malizia JP, Shakoor A (2018) Effect of water content and density on strength and deformation behavior of clay soils. Eng Geol 244:125-131. https://doi.org/10. 1016/j.enggeo.2018.07.028

Marfai MA, King L, Singh LP, Mardiatno D, Sartohadi J, Hadmoko DS, Dewi A (2008) Natural hazards in Central Java Province, Indonesia : an overview. Environ Geol 56:335-351. https://doi.org/10.1007/s00254-007-1169-9

Mhazo N, Chivenge P, Chaplot V (2016) Tillage impact on soil erosion by water: discrepancies due to climate and soil characteristics. Agric Ecosyst Environ 230:231-241. https://doi.org/10.1016/j.agee.2016.04.033

National Disaster Management Agency (2019). Data Informasi Bencana Indonesia. Badan Nasional Penanggulangan Bencana Indonesia. https://bnpb.cloud/ dibi/.

Noviyanto A, Purwanto MS, Supriyadi (2017) The assessment of soil quality of various age of land reclamation after coal mining : a chronosequence study. J Degraded Mining Lands Manage 5(1):1009-1018. https://doi.org/10.15243/ jdm/m.2017.051.1009

Pal DK, Wani SP, Sahrawat KL (2012) Vertisols of tropical Indian environments Pedology and edaphology. Geoderma 189-190:28-49. https://doi.org/10. 1016/j.geoderma.2012.04.021

Pal DK, Wani SP, Sahrawat KL, Srivastava P (2014) Red ferruginous soils of tropical Indian environments : a review of the pedogenic processes and its implications for edaphology. Catena 121:260-278. https://doi.org/10.1016/j. catena.2014.05.023

Pierre TJ, Primus AT, Simon BD, Philemon ZZ, Hamadjida G, Monique A, Pierre NJ, Lucien BD (2019) Characteristics, classification and genesis of vertisols under seasonally contrasted climate in the Lake Chad Basin, Central Africa. J Afr Earth Sci 150:176-193. https://doi.org/10.1016/j.jafrearsci.2018.11.003

Pirajno F (2009) Hydrothermal processes and mineral systems. Springer, Dordrecht. Retrieved from, Dordrecht. https://doi.org/10.1007/978-1-40208613-7

Piron D, Boizard H, Heddadj D, Pérès G, Hallaire V, Cluzeau D (2017) Indicators of earthworm bioturbation to improve visual assessment of soil structure. Soil Tillage Res 173:53-63. https://doi.org/10.1016/j.still.2016.10.013

Pulungan NA, Sartohadi J (2018a) New approach to soil formation in the transitional landscape zone : weathering and alteration of parent rocks. J Environ 5(1):1-7. https://doi.org/10.20448/journal.505.2018.51.1.7

Pulungan NA, Sartohadi J (2018b) Variability of soil development in hilly region, Bogowonto catchment, Java, Indonesia. Int J Soil Sci 13(1):1-8. https://doi. org/10.3923/ijss.2018.1.8

Ray RL, De Smedt F (2009) Slope stability analysis on a regional scale using GIS a case study from Dhading, Nepal. Environ Geol 57:1603-1611. https://doi. org/10.1007/s00254-008-1435-5

Regmi AD, Yoshida K, Dhital MR, Devkota K (2013) Effect of rock weathering, clay mineralogy, and geological structures in the formation of large landslide, a case study from Dumre Besei landslide, Lesser Himalaya Nepal. Landslide 10: 1-13. https://doi.org/10.1007/s10346-011-0311-7

Román-sánchez A, Reimann T, Wallinga J, Vanwalleghem T (2019) Bioturbation and erosion rates along the soil-hillslope conveyor belt, part 1 : Insights from single-grain feldspar luminescence. Earth Surf Process Landf 44:20512065. https://doi.org/10.1002/esp.4628

Ruiz S, Or D, Schymanski SJ (2015) Soil penetration by earthworms and plant roots - mechanical energetics of Bioturbation of compacted soils. PLoS One 10(6):1-26. https://doi.org/10.1371/journal.pone.0128914

Sambodo AP, Setiawan MA, Rokhmaningtyas RP (2018) The evaluation of modified productivity index method on the transitional volcanic-tropical landscape. IOP Conference Series 200(1):1-9. https://doi.org/10.1088/17551315/200/1/012011

Sartohadi J, Pulungan NAHJ, Nurudin M, Wahyudi W (2018) The ecological perspective of landslides at soils with high clay content in the middle Bogowonto watershed, Central Java, Indonesia. Appl Environ Soil Sci 2018:19. https://doi.org/10.1155/2018/2648185

Schaetzl RJ, Anderson S (2005) Soils genesis and geomorphology. Cambridge University Press, New York ISBN: 978-0-511-11104-4 Retrieved from www. cambridge.org/9780521812016

Schoeneberger PJ, Wysocki DA, Benham EC, Soil Survey Staff (2012) Field book for describing and sampling soils, version 3.0. Natural Resources Conservation Service. National Soil Survey Center, Lincoln Retrieved from https://books. google.com/books?hl=it\&lr=\&id=nmfK6wJuls8C\&pgis=1
Schrumpf M, Guggenberger G, Valarezo C, Zech W (2001) Tropical montane rain forest soils: development and nutrient status along an altitudinal gradient in the south Ecuadorian Andes. Erde 132(1):43-59 Retrieved from http://eref. uni-bayreuth.de/id/eprint/22821

Sidle RC, Ochiai H (2006) LANDSLIDES processes, prediction, and land use. American Geophysical Union, Washington DC ISBN: 978-0-87590-322-4

Sparling G, Ross D, Trustrum N, Arnold G, West A, Speir T, Schipper L (2003) Recovery of topsoil characteristics after landslip erosion in dry hill country of New Zealand, and a test of the space-for-time hypothesis. Soil Biol Biochem 35:1575-1586. https://doi.org/10.1016/j.soilbio.2003.08.002

Szokoli K, Szarka L, Metwaly M, Kalmar J, Pracser E, Szalai S (2018) Characterisation of a landslide by its fracture system using electric resistivity tomography and pressure probe methods. Acta Geod Geophys 53:15-30. https://doi.org/10. 1007/s40328-017-0199-3

Van Bemmelen RW (1949) The geology of Indonesia Vol. I A. The Netherland Goverment Printing

Van Eynde E, Dondeyne S, Isabirye M, Deckers J, Poesen J (2017) Impact of landslides on soil characteristics: implications for estimating their age. Catena 157:173-179. https://doi.org/10.1016/j.catena.2017.05.003

Whitesides CJ (2015) The bioturbation of Olympic marmots (Marmota olympus) and their impacts on soil properties. Phys Geogr 36(3):202-214. https://doi. org/10.1080/02723646.2015.1035625

Wida WA, Maas A, Sartohadi J (2019) Pedogenesis of Mt. Sumbing volcanic ash above the alteration clay layer in the formation of landslide susceptible soils in Bompon sub-watershed. Ilmu Pertanian (Agricultural Science) 4(1):15-22. https://doi.org/10.22146/ipas.41893

Yu B, Zhu Y, Liu Y (2017) Topographical factor-based shallow landslide hazard assessment : a case of Dayi area of Guizhou Province in China. Geoenvironmental Disasters 4(24):1-17. https://doi.org/10.1186/s40677-0170088-7

\section{Publisher's Note}

Springer Nature remains neutral with regard to jurisdictional claims in published maps and institutional affiliations.

\section{Submit your manuscript to a SpringerOpen ${ }^{\circ}$ journal and benefit from:}

- Convenient online submission

- Rigorous peer review

- Open access: articles freely available online

- High visibility within the field

- Retaining the copyright to your article

Submit your next manuscript at $\boldsymbol{\nabla}$ springeropen.com 